\title{
INDEXING AND ABSTRACTING
}

Signifikan: Jurnal Ilmu Ekonomi (Journal of Economics) is accredited by Ministry of Research, Technology and Higher Education Republic of Indonesia No. 036a/KPT/2016 Since May 23, 2016 (valid until May 2021)

Signifikan: Jurnal Ilmu Ekonomi (Journal of Economics) has been covered (indexed and abstracted) by following indexing services:

- Directory of Open Access Journal (DOAJ)

- CrossRef

- Ebsco (Open Access Directory)

- Ulrich's Periodical Database

- Goggle Scholar

- Portal Garuda

- Indonesian Scientific Journal Database (ISJD)

- Moraref

- Indonesia OneSearch

- Bielefiedl Academic Search Engine (BASE)

- Open Archive Initiative (OAI)

- Open Access Library

- Academic Keys

- Open Academic Journal Index

- Research Bible

- Cite Factor

- Eurasian Scientific Journal Index

- SciLit

- Harvard Library

- University of Oxford

- Boston University Library

- Ghent University Library

- Leiden University Library

- Imperial College London Library

- Universia

- The University of Sheffield Library

- University of Saskatchewan Library

- Stanford University Library

- Scholar Steer

- Directory of Abstract Indexing for Journal

- Turkish Education Index

- Directory of Research Journal Indexing

- Journal Index 


\section{ABOUT AUTHORS}

Afzal Ahmed is Faculty member at Shaheed Zulfikar Ali Bhutto Institute of Science and Technology (SZABIST) in the department of management sciences.

Amzul Rifin is a lecturer at Bogor Agricultural University. His research interest is Agribusiness and International Development.

Aunurrofik is a graduate student from Universitas Indonesia. He finished his M.Sc from Univesity of Groningen and Master of Science in Economics from Universitas Indonesia.

Arisman is a lecturer from State Islamic University (UIN) Syarif Hidayatullah Jakarta. Currently he is executive director of Center for Southeast Asian Studies (CSEAS).

Fanny Suzuda Pohan is a researcher from Universitas Trilogi. His research interest is in Economics studies.

Farhan Ahmed is Faculty member at Shaheed Zulfikar Ali Bhutto Institute of Science and Technology (SZABIST) in the department of management sciences. His research interest is Economics \& Finance.

Lestari Agus Salim is lecturer at Universitas Trilogi. He finished his bachelor degree and master degree from Bogor Agricultural University.

Joseph David is a researcher in economics from Ibrahim Badamasi Babangida (IBB), Nigeria. His research interest is in economics.

Miranda Febriningtyas is a researcher at Bogor Agricultural University. She finished her master degree from Bogor Agricultural University.
Muhammad Irsyad Ilham is a data analyst at Central Bureau of Statistics, Republic of Indonesia. He finished his bachelor degree from School of Statistics Science.

Musa Abdullahi Sakanko is lecturer at IBB University. He obtained his B.Ec from IBB University and M.Sc in Economics from University of Abuja Nigeria.

Restuning Dyah Widyanti is a civil servant in Provincial Government of The Special Capital Region Jakarta. She fnisihed her Master of Economics from Universitas Indonesia and M.Sc. in Economics, Planning and Public Policy from National Graduate Institute for Policy Studies (GRIPS), Tokyo, Japan.

Rina Juliet Artami holds a master degree in public policy at the Graduate National Institute for Policy Studies in Tokyo. She is also hold master of science in economics at the Universitas Indonesia and a staff in Directorate General of Oil and Gas, Ministry of Energy and Mineral Resources, Indonesia.

Rina Oktaviani is a professor from Bogor Agricultural University. She currently as a Director of International Trade and Economic Policy Studies.

Sahabia Kanwal is working as an account executive at Citi Bank Pakistan. Her research interest is in industrial behavior studies.

Yonosuke Hara is lecturer at National Graduate Institute for Policy Studies, Japan. He finished his Ph.D in Agricultural Economics from University of Tokyo. 


\section{COPYRIGHT TRANSFER AGREEMENT}

Authors submitting a manuscript do so on the understanding that if accepted for publication, copyright of the article shall be assigned to Signifikan: Jurnal Ilmu Ekonomi (Journal of Economics) as publisher of this journal.

Copyright encompasses exclusive rights to reproduce and deliver the article in all forms and media, including reprints, photographs, microfilms and any other similar reproductions, as well as translations. The reproduction of any part of this journal, its storage in databases and its transmission by any forms or media, such as electronic, electrostatic and mechanical copies, photocopies, recordings, magnetic media, etc., will be allowed only with a written permission from Signifikan: Jurnal Ilmu Ekonomi (Journal of Economics).

Signifikan: Jurnal Ilmu Ekonomi (Journal of Economics), Editors, and International Advisory Editorial Board make every effort to ensure that no wrong or misleading data, opinions or statements be published in the journal. In any way, the contents of the articles and advertisements published in Signifikan: Jurnal Ilmu Ekonomi (Journal of Economics) are sole and exclusive responsibility of their respective authors and advertisers.

The copyright form should be filled with respect to article and be signed originally and sent to the Editorial Office in the form of original mail, or scanned document file (softcopy) to:

\section{Nur Rianto Al Arif}

Editorial Office Signifikan

Faculty of Economics and Business

Syarif Hidayatullah State Islamic University Jakarta

Jl Ir H Juanda No 95, Ciputat, South Tangerang, Banten, Indonesia -15412-

Phone (+6221) 7493318, Fax. (+6221) 7496006

Website: www.journal.uinjkt.ac.id/index.php/signifikan

Email: signifikan@uinjkt.ac.id 


\section{Copyright Transfer Agreement}

Name of Principal Authors:

Address of Principal Authors:

Tel/Fax:

E-mail:

Author(s) Name:

Manuscript Title:

Date Received:

1. I/We submit to the Signifikan: Jurnal Ilmu Ekonomi (Journal of Economics). I/We certify that the work reported here has not been published before and contains no materials the publication of which would violate any copyright or other personal or proprietary right of any person or entity.

2. I/We hereby agree to transfer to Signifikan: Jurnal Ilmu Ekonomi (Journal of Economics)/ Publisher for the copyright of the above - named manuscript.

3. I/We reserve the following: (1) All proprietary rights other than copyright such as patent rights. (2) The right to use all or part of this article in future works of our own such as in books and lectures. Print or Type Name and Title of Author.

Date:

Signature

(When there is more than one author, only the first author that sign this copyright) 


\section{SIGNIFIKAN}

\section{WRITING GUIDANCE FOR JOURNAL OF SIGNIFIKAN}

1. The manuscripts represent academic research in economics discipline.

2. Upon the publication of the manuscript, the author should provide a letter states that the manuscripts have never been, or under consideration to be, published in other journal publications.

3. Structure of the manuscripts

a. Title. The title should be short, clear, and informative, but does not exceed 9 words.

b. Author's names and institutions. The author's names should be accompanied by the author's institutions and email addresses, without any academic titles and/or job title.

c. Abstract and keywords. The abstract should be less than 150 words. The key words should be 2 to 5 phrases.

d. Introduction. This section explains the background of the study, and aims of the manuscripts. It should be written without numbers and/or pointers.

e. Methods. This section describes the tools of analysis along with the data and their sources. f. Result and Discussion. This section explains the results of the study.

g. Conclusions. This section concludes and provides policy implications, if any, of the study.

h. References. This section lists only the papers, books, or other types of publications referred in the manuscript.

4. The authors should provide an index of subject, namely the specific term in the manuscript. The authors should also provide the index of authors, namely the key authors of papers referred in the manuscript. Please write the family name followed by the given name.

5. Estimation result from a software package is not allowed to be directly presents in the paper. They should be presented in equations with the appropriate estimation results.

6. Table format should contain only heading and contents. Please provide the top and bottom lines, along with the line(s) that separate the heading and the contents. Example:

Table 1. Quality of Life Index (Selected Countries)

\begin{tabular}{lcc}
\hline Countries & $\mathbf{2 0 0 5}$ & $\mathbf{2 0 1 3}$ \\
\hline ASEAN Countries & & \\
Indonesia & $5,814(71)$ & $5,54(71)$ \\
Malaysia & $6,608(36)$ & $6,62(36)$ \\
Thailand & $6,436(42)$ & $5,96(50)$ \\
Filipina & $6,403(44)$ & $5,71(63)$ \\
Singapura & $7,719(11)$ & $8,00(6)$ \\
Vietnam & $6,080(61)$ & $5,64(68)$ \\
\hline
\end{tabular}

Source: Economist Intelegence Unit

7. The manuscript is prepared in a quarto paper, single-sided, and double-space format. A new paragraph should start 5 characters from the left margin, using 12-size, times-new-romans font type. 
8. The manuscript is written in proper English, either British or American English, but not the combination of both, except for special editions.

9. The manuscript should be in no less than 25 pages long.

10. The top and bottom margins are 1 inch.

11. The title is written using capital letters of 14 font size, centre position.

12. Sub titles are written using capital letters, started from the left margin.

13. Sub of sub titles are written using capital letters only at the beginning of each word except for connecting words. They should be started from the left margin.

14. References should be those of the last ten years publication, unless they are key references.

15. Citation in the text body should be written using the family name and years of publication. Example:

a. Hill (2001) suggests that the objective of depreciation ....

b. According to Kotler (2010), intra industry trade can be ...

c. Wagner (in McCain, 1990) states that ...

d. The definition of flypaper effect is ... (Wagner, 1976).

16. Tables and figures should be presented as follows:

a. The name of tables and figures should follow a numbering system (Arabic numbering system). The names of the tables and figures are on the top and bottom parts of the tables, respectively.

b. The tables and figures should provide the source of information, if any, at the bottom part of both.

17. References should be written in alphabetical order, without any number. They should be written using the following criteria:

a. For books, the format should follow the following example:

Al Arif, M. N. R. 2015. Pemasaran Stratejik Pada Asuransi Syariah. Jakarta: Gramata.

b. For papers that are part of a book, the format should follow the following example:

Bahl, R. 2000. How to Design a Fiscal Decentralization. in Sahid, Y. (eds.), Local Dynamics in an Era of Globalization, 25-26, London: Oxford University Press.

c. For journal/magazine papers, the format should follow the following example:

Al Arif, M. N. R. 2012. Efek Multiplier Wakaf Uang dan Pengaruhnya Terhadap Program Pengentasan Kemiskinan. Jurnal Asy-Syir'ah, Vol. 46 (1), Januari 2012, hlm. 10 - 12.

18. The manuscript in microsoft word should be sent to signifikan@uinjkt.ac.id or through online submission at:http://journal.uinjkt.ac.id/index.php/signifikan/user/register

19. A brief CV that records full name, academic title, institution, telephone, fax and mobile number should accompany the manuscript.

20. The decision of the manuscript are:
a. Accepted, or
b. Accepted with minor revision, or
c. Accepted with major revision, or
d. Rejected.

21. Upon the publication of the manuscript in the journal, the author will receive a publication proof number and 2 off-prints.

22. Further information about the journal can be seen at http://journal.uinjkt.ac.id/index.php/ signifikan 